\title{
17. NEW CALCAREOUS NANNOFOSSIL TAXA FROM THE JURASSIC/CRETACEOUS BOUNDARY INTERVAL OF SITES 765 AND 261, ARGO ABYSSAL PLAIN ${ }^{1}$
}

\author{
Paul R. Bown ${ }^{2}$
}

\begin{abstract}
A summary of calcareous nannofossil biostratigraphy performed for Late Jurassic (Kimmeridgian) to Early Cretaceous (Hauterivian) cores of Site 765 (Cores 123-765C-58R to -55R) and Site 261 (Cores 27-261-33 to -27), Argo Abyssal Plain, off northwestern Australia is presented. Precise age determinations were limited by variable preservation and the exclusion of a number of marker species due to provincialism. However, the presence of species, such as, Stephanolithion bigotii bigotii, Watznaueria manivitae, Tubodiscus verenae, and Cruciellipsis cuvillieri results in a reasonably good degree of biostratigraphic control. Biogeographic interpretation of the nannofossil data suggests that the Argo Basin occupied a position transitional between the Tethyan and Austral nannofloral realms. A cooler water regime is suggested by the absence of thermophyllic Tethyan forms, such as Nannoconus, and the presence of taxa that display bipolar distribution, such as Crucibiscutum salebrosum. Two new species, Zeugrhabdotus cooperi and Cyclagelosphaera argoensis, and one new combination, Haqius ellipticus are described.
\end{abstract}

\section{INTRODUCTION}

Calcareous nannofossils were analyzed from the Late Jurassic (Kimmeridgian) to Early Cretaceous (Hauterivian) cores of Site 765 (Cores 123-765C-58R to -55R) and Site 261 (Cores 27-26133 to -27), Argo Abyssal Plain, off northwestern Australia (Fig. 1). Age determinations along with lithostratigraphy were used to perform an integrated correlation of the two sites (Dumoulin and Bown, this volume). Taxonomic comments are presented here, and two new species, Zeugrhabdotus cooperi and Cyclagelosphaera argoensis, and one new combination, Haqius ellipticus, are described.

\section{BIOSTRATIGRAPHIC SUMMARY}

The nannofossil biostratigraphy of these two sites is problematic because of the following factors:

1. The considerable distance from the areas in which existing Mesozoic biostratigraphic zonation schemes were established (i.e., Europe and the North Atlantic Ocean).

2. The effects of nannofloral provincialism.

3. The relatively poor preservation (and barren intervals) that resulted in lowered diversities, and the probability that certain marker species are absent or rare and have truncated ranges.

For these reasons, selected bioevents were used for sediment dating, and I am confident that a reasonably good degree of biostratigraphic control has been achieved. Biostratigraphic datums were selected from the following sources: Bown et al. (1988); Bralower (1987); Bralower et al. (1989); Cooper (1985); Crux (1989); Jakubowski (1987); and Roth et al. (1983). The age determinations given below differ from those originally presented in Ludden, Gradstein, et al. (1990) and Proto Decima (1974).

\section{Site 765}

The lowest nannofossil-bearing interval, $3.18 \mathrm{~m}$ above basement, ranges from Samples 123-765C-62R-2, $61 \mathrm{~cm}$, to -61R-3,

\footnotetext{
${ }^{1}$ Gradstein, F. M., Ludden, J. N., et al., 1992. Proc, ODP. Sci. Results, 123 College Station, TX (Ocean Drilling Program).

Department of Geological Sciences, University College London, Gower Street, London WC1E 6BT, U.K.
}

$3 \mathrm{~cm}$. The assemblages from this interval are impoverished and poorly preserved, but do occur consistently throughout (Table 1). The assemblages are characterized by common, large $(20 \mu \mathrm{m})$ Watznaueria manivitae coccoliths, which are highly corroded. Also present are poorly preserved specimens of Watznaueria barnesae, W. britannica, and W. fossacincta, along with etched retecapsid coccolith rims. These assemblages have been altered by selective etching probably because of in-situ deposition below the calcite compensation depth (CCD). The abundance of $W$. manivitae correlates with similar assemblages from Site 261 (27$261-32-4,140 \mathrm{~cm}$, to $-32-3,10 \mathrm{~cm}$ ), which have been dated as Tithonian.

The second nannofossil-bearing interval ranges from Samples 123-765C-58R-2, $10 \mathrm{~cm}$, to 123-765C-55R-1, $5 \mathrm{~cm}$ (Table 2). Assemblages are relatively well-preserved and diverse, reflecting their original deposition above the CCD, prior to transport onto the abyssal plain as carbonate turbidites. The interval has been dated as Valanginian to Hauterivian on the basis of the occurrence of Tubodiscus verenae (Samples 123-765C-58R-1, $85 \mathrm{~cm}$, to $-56 \mathrm{R}-3,142 \mathrm{~cm}$ ) and Cruciellipsis cuvillieri (throughout). Tubodiscus verenae has a range restricted to the Valanginian (Roth, 1978; Perch-Nielsen, 1985; Bralower, 1987), although Applegate et al. (1989) recently recorded its presence in the Hauterivian. Further work will be needed to substantiate this claim. The presence of Cruciellipsis cuvillieri throughout this interval infers an age no younger than Hauterivian (Bralower, 1987). The lowest occurrence of Eiffellithus windii in Sample 123-765C-58R-1, 56 $\mathrm{cm}$, is also indicative of an early Valanginian age (Bralower et al., 1989). The occurrence of Vagalapilla matalosa and Repagulum parvidentatum in Valanginian and Hauterivian sediments is unique to this region; neither species has been reported from sediments older than Barremian (Jakubowski, 1987; Crux, 1989).

The assemblages from this interval correlate well with those from Site 261, from Samples 27-261-30-2, $60 \mathrm{~cm}$, to $-28-1,70$ $\mathrm{cm}$.

\section{Site 261}

Calcareous nannofossils were found consistently throughout the lower Cores 27-261-33 to -27 of Site 261. The interval was dated as Kimmeridgian to Hauterivian (Table 3).

The interval 27-261-33-1, $59 \mathrm{~cm}$, to $-33-1,10 \mathrm{~cm}$, has been dated as Kimmeridgian/early Tithonian on the basis of the occurrence of Stephanolithion bigotii bigotii, which has a last occur- 


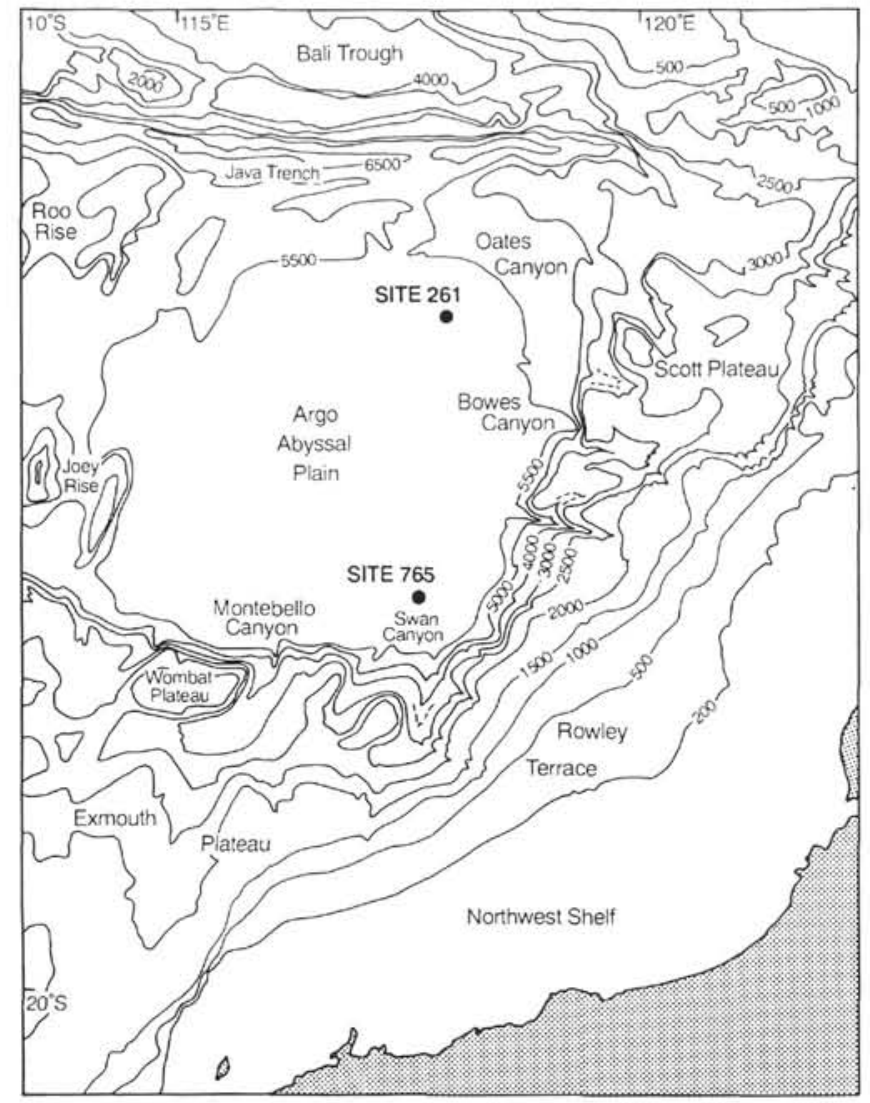

Figure 1. Regional setting and location of Sites 765 and 261. Contours in meters.

rence in the early Tithonian (Bown et al., 1988; Bralower et al., 1989), and the absence of Lotharingius crucicentralis, Podorhabdus grassei, Crepidolithus perforata, and Hexapodorhabdus cuvillieri, which suggests an age no older than Kimmeridgian (Bown et al., 1988). In addition, Conusphaera mexicana minor, found in the top sample of this interval (27-261-33-1, $10 \mathrm{~cm})$, has a first occurrence in the latest Kimmeridgian (sensu gallico) (Bralower et al., 1989), and the presence of coccoliths transitional in morphology between Zeugrhabdotus erectus and Z. embergeri (e.g., Zeugrhabdotus sp. 1 and Z. cooperi) suggests a Kimmeridgian to Tithonian age (Roth, 1983). Preservation in Core 27-261-33 is good throughout, and the assemblages are entirely compatible stratigraphically.

Samples from interbasalt limestones (27-261-34-1, 64-63 cm, and $-33-1,82-54 \mathrm{~cm}$ ) yielded rare and poorly preserved assemblages that are not age-diagnostic.

The interval $27-261-33-1,5 \mathrm{~cm}$, to $-31-3,41 \mathrm{~cm}$, has been dated as Tithonian based on the highest occurrence of Stephanolithion bigotii bigotii, which indicates an early Tithonian age, and the lowest occurrence of Cruciellipsis cuvillieri, which has a first occurrence in the latest Tithonian (Bralower et al., 1989). The nannofossil taxon most useful for defining the Jurassic/Cretaceous boundary, Nannoconus, is not present in the Site 261 section as a result of provincialism. Determination of the exact position of the Jurassic/Cretaceous boundary was further impeded by poor preservation and barren intervals in this part of the section. The lowest occurrence of $C$. cuvillieri was used to approximate the Jurassic/Cretaceous boundary. The lower part of this interval $(27-261-32-4,140 \mathrm{~cm}$, to $-32-3,10 \mathrm{~cm})$ is characterized by the numerical dominance of large specimens $(20 \mu \mathrm{m})$ of Watznaueria manivitae. The abundance of this species is indicative of a Tithonian age; however, numbers declined sharply toward the top of the stage. This decline in abundance of $W$. manivitae (and also W. britannica and W. barnesae), followed by a distinct increase in the abundance of $W$. fossacincta, also indicates the proximity of the Jurassic/Cretaceous boundary (Cooper, 1985). This interval also includes the lowest occurrences of $\mathrm{Mi}$ crostaurus chiastius, Lithraphidites carniolensis, Pickelhaube furtiva, Zeugrhabdotus embergeri, and Ethmorhabdus hauterivianus, all of which have first occurrences in the Latest Jurassic (Bralower et al., 1989).

The interval $27-261-31-3,40 \mathrm{~cm}$, to $-30-2,130 \mathrm{~cm}$, has been dated as Berriasian based on the lowest occurrence of $C$. cuvillieri, used here to approximate the Jurassic/Cretaceous boundary, and the lowest occurrence of $T$. verenae, which has a first occurrence in the lowermost Valanginian. The lowest occurrence of Crucibiscutum salebrosum in Sample 27-261-31-2, $129 \mathrm{~cm}$, and Rhagodiscus nebulosus in Sample 27-261-30-3, $140 \mathrm{~cm}$, confirms a definite (possibly late) Berriasian age (Jakubowski, 1987; Bralower et al., 1989) for the upper part of this interval.

The interval from Sample 27-261-30-2, $60 \mathrm{~cm}$, to $-28-2,128$ $\mathrm{cm}$, has been dated as Valanginian using the occurrence of Tubodiscus verenae, which has a restricted range in the Valanginian (Bralower, 1987; Bralower et al., 1989). The occurrence of Tegumentum striatum in Sample 27-261-28-2, $128 \mathrm{~cm}$, is indicative of a Valanginian to early Hauterivian age (Crux, 1989; Mutterlose, this volume).

The interval from Sample 27-261-28-2, $121 \mathrm{~cm}$, to -27-2, 57 $\mathrm{cm}$, has been dated as late Valanginian to Hauterivian based on the highest occurrence of Tubodiscus verenae (last occurrence, late Valanginian) and the continued presence of Cruciellipsis cuvillieri (last occurrence, late Hautervivian).

\section{BIOGEOGRAPHIC IMPLICATIONS}

The nannofossil assemblages from Sites 765 and 261 are largely composed of cosmopolitan species and, preservation permitting, display normal diversities that are indicative of openocean environments. However, important features of these assemblages distinguish them from those observed in both the Boreal (e.g., Cooper, 1989; Crux, 1989) and Tethyan (e.g., Bralower et al., 1989) areas and point to their occupying a position at the southern limit of the Tethyan nannofloral realm or within a southern, high-latitude, Austral realm (Wise, 1988; Dumoulin and Bown, this volume). Such an interpretation is in agreement with the paleolatitude determined for these sites (i.e., about $35^{\circ} \mathrm{S}$ during the Late Jurassic-Early Cretaceous; Ogg et al., this volume). The sites were separated from the European proto-North Atlantic area during this time by the large Neotethys Ocean.

The most significant biogeographic evidence is the total or near-total exclusion of Tethyan taxa, whose distribution is thought to be primarily controlled by temperature. The most important absent group is Nannoconus, which was diverse and abundant in the Tethyan area during this time, but others include Conusphaera mexicana mexicana, Calcicalathina oblongata, and Diadorhombus rectus. A number of other species, considered to be Tethyan, appear to have had greater ecological tolerance, as evidenced by their sparse and sporadic occurrence in the Boreal area, and these are also present in the Argo assemblages (e.g., Cruciellipsis cuvillieri, Tubodiscus verenae, Speetonia colligata, Rhagodiscus asper). The occurrence of abundant W. manivitae is the most positive evidence for Tethyan influence (Cooper, 1989), but this appears to have been limited to the Late Jurassic (i.e., Tithonian).

Affinities with the northern (and southern) high-latitude regions are demonstrated by the presence of Crucibiscutum salebrosum and Seribiscutum primitivum (in the Aptian-Albian section), 
Table 1. Stratigraphic distribution of calcareous nannofossils from Site 765 (Cores 123-765C-62R to -61R).

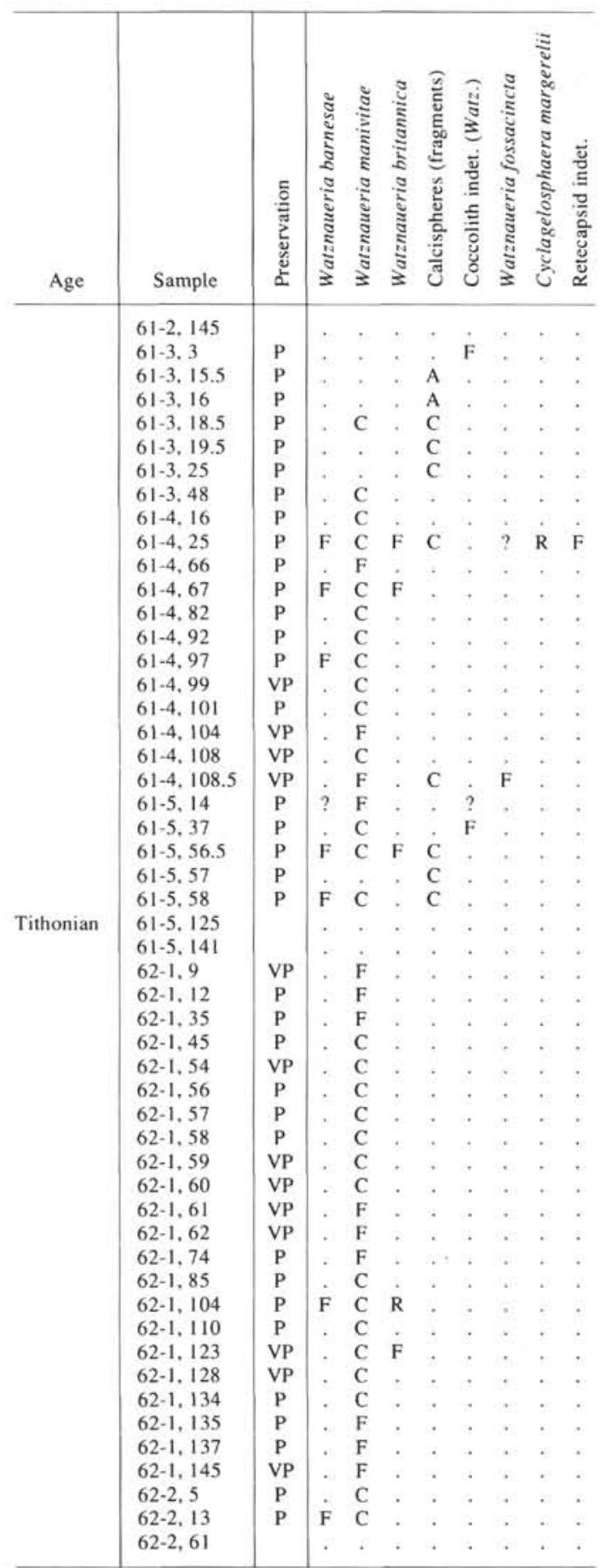

Abbreviations used in calcareous nannofossil range charts (Tables through 3 ) are (1) for abundance: $\mathrm{R}=$ rare ( $1-2$ specimens); $\mathrm{F}=$ few ( $3-10$ specimens); $\mathrm{C}=$ common $(11-100$ specimens); $\mathrm{A}=$ abundant (greater than 100 specimens); counting was performed using the light microscope over 20 fields of view; (2) for preservation: $\mathrm{VP}=$ very poor (extreme etching) $\mathrm{P}=$ poor (etching and overgrowth; obscured, damaged, or destroyed central area structures); $\mathrm{M}=$ moderate (moderate etching or overgrowth); $\mathrm{G}$ $=\operatorname{good}$ (little or no etching or overgrowth). which are rare or absent in the Tethyan realm. These striking bipolar distributions have been confirmed by reports of their occurrence in other southern ocean sites (e.g., Weddell Sea [Mutterlose and Wise, 1990], Falkland Plateau [Wise, 1983]). The absence of certain Boreal taxa (e.g., Sollasites arcuatus, Micrantholithus speetonensis, and Tegulalithus septentrionalis), suggests that these forms were restricted to the northern high-latitude province.

The only endemic nannofossil species at these sites are $\mathrm{Va}$ galapilla matalosa and Repagulum parvidentatum, however, from the Barremian onward these species had a far wider geographical distribution (Crux, 1989).

These nannofossil assemblages exhibit biogeographic characteristics that are most like those seen in the northern (and southern) high latitudes. They suggest the existence of a Southern Hemisphere mid- to high-latitude Austral nannofloral realm, which is equivalent to the Boreal realm of the Northern Hemisphere. These distribution patterns are best explained by temperate surface-water temperatures in the Argo Basin, reflecting latitudinally zoned climatic differences and/or the modifying influence of southern ocean currents (Baumgartner, this volume; Baumgartner et al., this volume). As in the Northern Hemisphere, it is likely that biogeographic differences become significant poleward of $30^{\circ}$ to $40^{\circ}$.

\section{SYSTEMATIC TAXONOMY}

\section{Family WATZNAUERIACEAE Rood et al., 1971 Genus CYCLAGELOSPHAERA Noël, 1965 Cyclagelosphaera argoensis sp. nov.} (Pl. 1; Figs. 1-4, 8, 9, 11, 12)

Diagnosis. A large, concavo-convex species of Cyclagelosphaera $(6-11 \mu \mathrm{m})$ having a broad, distal shield inner cycle and a small central perforation.

Description. A large, circular coccolith having characteristic watznaueriacean structure (Bown, 1987). The distal shield consists of a convex outer cycle of about 32 imbricating elements joined along inclined sutures, and an inner cycle composed of elements joined along complex sutures. The inner cycle may be as broad as, or slightly less broad than the outer cycle. A third, narrow, inner wall cycle surrounds a small central perforation.

In the light microscope, the coccolith displays high birefringence colors, reflecting the thickness of the shields, and the distal inner cycle forms a high tube-like structure that surrounds the central perforation. This inner cycle appears to flare when the microscope stage is racked up and down.

Size. Diameter: 6-11.5 (8.8) $\mu \mathrm{m}$. Holotype dimensions in brackets.

Differentiation. C. argoensis is distinguished from other species of Cyclagelosphaera by its large size; convexity; and broad, blocky, distal inner cycle. The structure of the distal inner cycle is distinctive when observed in light microscope and distinguishes this species from other large forms, such as Cyclagelosphaera deflandrei.

Derivation of name. Named after the type locality, DSDP Site 261, Argo Abyssal Plain, off the northwestern shelf of Australia.

Holotype. UCL-2999-33 (Pl. 1, Fig. 1); UCL figures refer to film and frame numbers that are stored in the Postgraduate Unit of Micropalaeontology, University College London.

Isotypes. UCL-2999-28 (PI. 1, Fig. 4); UCL-2948-21 (Pl. 1, Fig. 11); UCL-2948-22 (Pl. 1, Fig. 9).

Type locality. DSDP Site 261, Argo Abyssal Plain, off the northwest shelf of Australia.

Type level. DSDP 27-261-31-CC; Tithonian.

Occurrence. DSDP Site 261, Tithonian to Valanginian; ODP Site 765 , Berriasian to Hautervivian.

Range. Tithonian to Hautervivian.

\section{Genus WATZNAUERIA Reinhardt, 1964 \\ Watznaueria manivitae Bukry, 1973}

$$
\text { (Pl. 1, Figs. 13-16, 24) }
$$

Remarks. The name $W$. manivitae is used for large watznaueriacean coccoliths $(>9 \mu \mathrm{m})$ that are distinctly elliptical, have a closed central area, 
Table 2. Stratigraphic distribution of calcareous nannofossils from Site 765 (Cores 123-765C-58R to -55R).

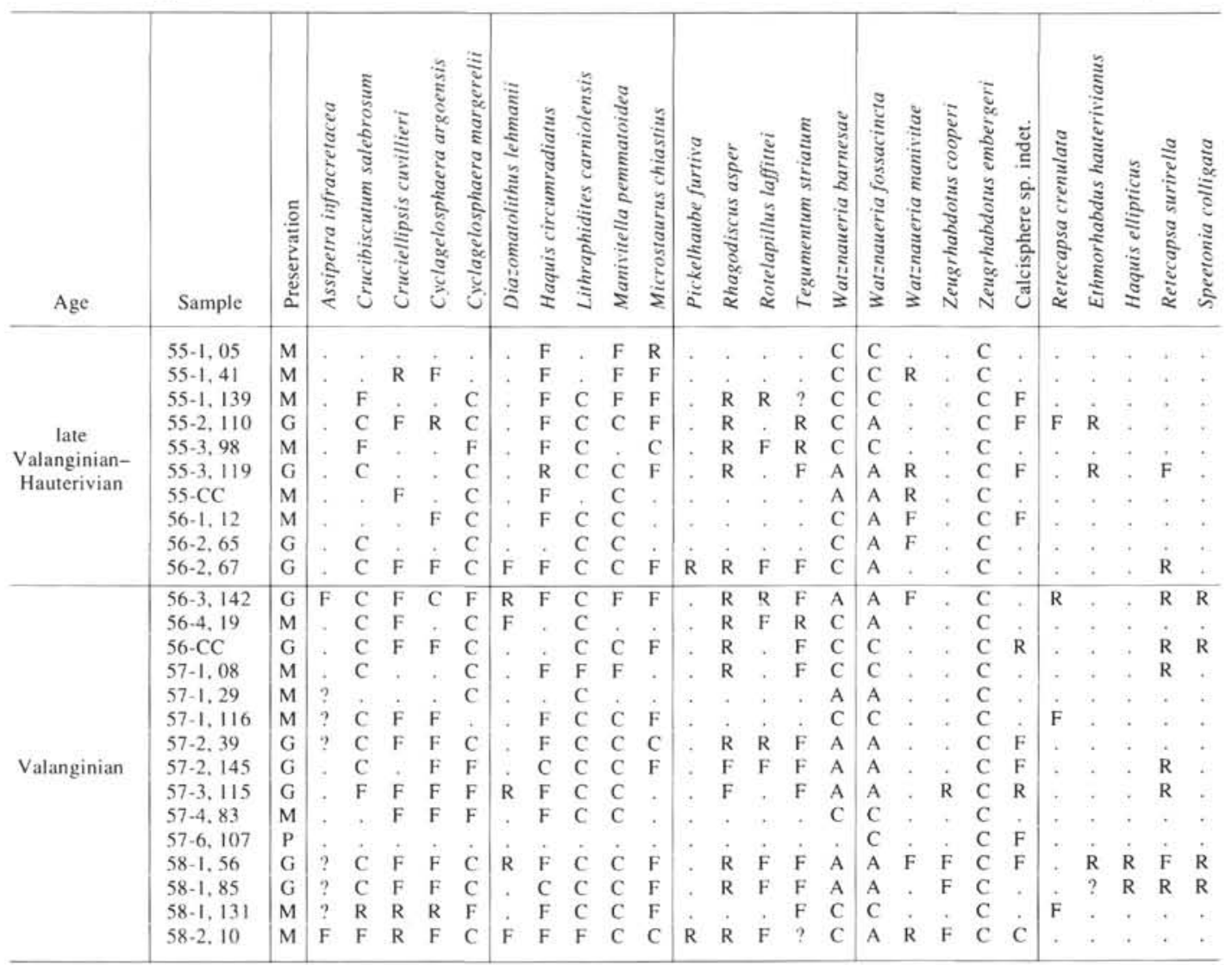

and display high birefringence colors in light microscope, between crossed nicols. The elliptical outline distinguishes this species from Cyclagelosphaera deflandrei. For a full discussion of the taxonomy of these two species, see Moshkovitz and Ehrlich (1987). The stratigraphic range of $W$. manivitae is not well constrained because of the taxonomic confusion with $C$. deflandrei. The latter species has a range given as Callovian/Kimmeridgian to Hauterivian (e.g., Roth,1973; Moshkovitz and Ehrlich, 1987), whereas reports of W. manivitae have been mostly restricted to the upper Callovian to Berriasian (Moshkovitz and Ehrlich, 1987). The occurrence of abundant W. manivitae during the Tithonian, as seen in the sediments of Sites 765 and 261, may prove to have biostratigraphic value.

Genus HAQUIS Roth, 1978

Haquis ellipticus (Grün in Grün and Allemann, 1975) comb, nov.

Markalius ellipticus Grün in Grün and Allemann, 1975, p. 200-201, Pl. IX, Figs. 7-12, Text-fig. 34.

Markalius ellipticus Grün; Bralower et al., 1989, p. 222, PI. VI, Figs. 4, 5.

Remarks. An elliptical species of Haquis, which is easily distinguished from the circular species, Haquis circumradiatus.

Family ZYGODISCACEAE Hay and Mohler, 1967 Genus ZEUGRHABDOTUS Reinhardt, 1965 Zeugrhabdotus cooperi $\mathrm{sp}$. nov.

$$
\text { (Pl. 2, Figs. 1-12) }
$$

Zygodiscus erectus (Deflandre) emend.; Bralower et al., 1989 (in part), p. 204; Pl. II, Figs. 7, 8 .

Diagnosis. A species of Zeugrhabdotus having a broad, blocky, high rim; a narrow, lens-shaped central area; and a broad transverse bar that is proximally situated.
Description. The rim structure is of typical Jurassic discolith type (Bown, 1987), similar to that of the Genus Crepidolithus. The prominent distal shield (wall) is composed of steeply inclined/imbricating elements. The proximal shield forms a thin basal disk and extends distally along the inner surface of the distal shield. The triangular cross section of the proximal shield is best seen in light microscope. The rim is high (3.0-4.5 $\mu \mathrm{m})$, usually about one-half the width of the coccolith, and broad, generally broader than the central area. The central area is narrow and lensshaped or may be almost completely closed up. In proximal view, a central area plate completely closes the central area, or two small semi-circular openings demarcate the transverse bar. The bar is broad and tapers outward from the center. Its position is also marked by a median groove and a small central perforation. The bar is best seen in the light microscope, where it appears as a broad, bright, diamond-shaped structure, that divides into two units to either side of the center. The broad, high, blocky rim; narrow central area; and broad transverse bar are distinctive in both plan and side views in the light microscope.

Size. Length: 7.5-10.0 (9.0) $\mu \mathrm{m}$. Width: 5.0-7.0 (6.6) $\mu \mathrm{m}$. Height: $3.0-4.5(3.3) \mu \mathrm{m}$. Holotype dimensions in brackets.

Differentiation. A broad, high rim and narrow, or closed, central area distinguish Z . cooperi from other species of Zeugrhabdotus. The broad, diamond-shaped bar distinguishes Z. cooperi from species of Crepidolithus.

Remarks. The taxonomy of Zeugrhabdotus from the Mesozoic is at present somewhat confused. In Upper Jurassic sediments, classification is complicated by the occurrence of variable morphologies (e.g., Zeugrhabdotus sp. 1, P1. 2, Figs. 18, 19, 21, 22, 25) associated with an evolutionary lineage from $Z$. erectus (Pl. 2, Figs. 23, 24) to Z. embergeri (Pl. 2, Figs. 13-17, 20). The transition is complex and still poorly understood and will not be discussed here; further discussion is given in Roth (1983) and Bralower et al. (1989).

Derivation of name. This species is named after the nannofossil scientist, Kevin Cooper. 
Table 2 (continued).

\begin{tabular}{|c|c|c|c|c|c|c|c|c|c|c|c|c|c|c|c|c|c|c|c|c|c|c|c|}
\hline Age & Sample & 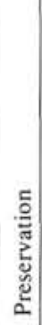 & 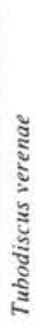 & 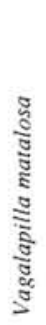 & 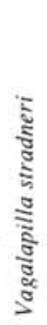 & 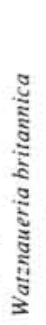 & 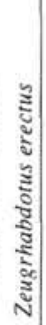 & 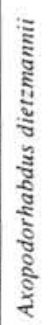 & 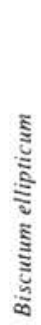 & 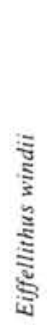 & 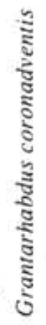 & 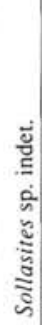 & 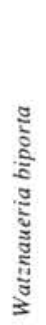 & 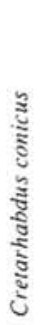 & 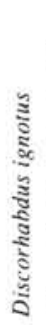 & 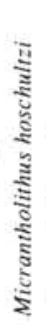 & 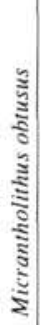 & 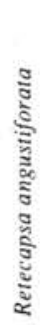 & 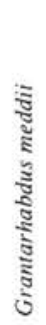 & 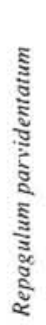 & 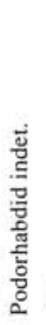 & $\begin{array}{l}0 \\
0 \\
\vdots \\
0 \\
z \\
0 \\
5 \\
0 \\
0 \\
0\end{array}$ & 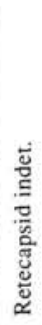 \\
\hline $\begin{array}{l}\text { late } \\
\text { Valanginian- } \\
\text { Hauterivian }\end{array}$ & $\begin{array}{l}55-1,05 \\
55-1,41 \\
55-1,139 \\
55-2,110 \\
55-3,98 \\
55-3,119 \\
55-\mathrm{CC} \\
56-1,12 \\
56-2,65 \\
56-2,67\end{array}$ & $\begin{array}{l}\mathrm{M} \\
\mathrm{M} \\
\mathrm{G} \\
\mathrm{M} \\
\mathrm{G} \\
\mathrm{M} \\
\mathrm{M} \\
\mathrm{G} \\
\mathrm{G}\end{array}$ & 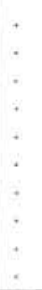 & $\begin{array}{l}\mathrm{F} \\
\dot{\mathrm{F}} \\
\mathrm{C} \\
\dot{\mathrm{C}} \\
\mathrm{C} \\
\mathrm{C} \\
\mathrm{C} \\
\mathrm{C}\end{array}$ & $\begin{array}{l}\dot{.} \\
\dot{\mathrm{F}} \\
\dot{.}\end{array}$ & $\begin{array}{l}\dot{\cdot} \\
\dot{\mathrm{F}} \\
\dot{\mathrm{F}} \\
\dot{\cdot}\end{array}$ & $\dot{.}$. & F & $\begin{array}{l}\dot{\mathrm{R}} \\
\mathrm{F} \\
\dot{2} \\
\dot{\mathrm{R}} \\
\dot{\mathrm{R}}\end{array}$ & $\begin{array}{l}\dot{5} \\
\dot{5} \\
\dot{5} \\
\dot{5} \\
\dot{5} \\
\dot{.}\end{array}$ & $\dot{\vec{F}} \dot{.}$ & $\begin{array}{l}\dot{ } \\
\mathrm{R} \\
\dot{\cdot} \\
\dot{\cdot} \\
\dot{\cdot} \\
\dot{\cdot}\end{array}$ & $\begin{array}{l}\dot{\vec{R}} \\
\dot{\mathrm{F}} \\
\dot{\mathrm{F}}\end{array}$ & $\begin{array}{l}\dot{.} \\
\mathrm{F} \\
\mathrm{F} \\
\mathrm{F} \\
\mathrm{F} \\
\dot{-} \\
\dot{\mathrm{F}}\end{array}$ & $\begin{array}{l}\dot{\mathrm{R}} \\
\dot{.} \\
\dot{.} \\
\dot{.}\end{array}$ & $\dot{\mathrm{F}}$ & $\begin{array}{l}\dot{.} \\
\dot{5} \\
\dot{5} \\
\dot{.}\end{array}$ & $\begin{array}{l}\dot{\mathrm{F}} \\
\dot{\mathrm{R}} \\
\dot{\dot{\mathrm{F}}}\end{array}$ & $\begin{array}{l}\dot{.} \\
\dot{.} \\
\dot{.} \\
\dot{.} \\
\dot{.}\end{array}$ & $\begin{array}{l}\dot{.} \\
\dot{F} \\
\text { F } \\
\dot{.} \\
\dot{.}\end{array}$ & $\dot{.} \cdot \dot{ }$ & $\begin{array}{l}\dot{ } \\
\dot{R} \\
\mathrm{R} \\
\dot{\mathrm{R}} \\
\dot{.} \\
\dot{.}\end{array}$ & $\begin{array}{c}\mathrm{F} \\
\mathrm{C} \\
\vdots \\
\dot{\mathrm{F}} \\
\dot{ } \\
\dot{ }\end{array}$ \\
\hline Valanginian & $\begin{array}{l}56-3,142 \\
56-4,19 \\
56-\mathrm{CC} \\
57-1,08 \\
57-1,29 \\
57-1,116 \\
57-2,39 \\
57-2,145 \\
57-3,115 \\
57-4,83 \\
57-6,107 \\
58-1,56 \\
58-1,85 \\
58-1,131 \\
58-2,10\end{array}$ & $\begin{array}{l}\text { G } \\
\text { M } \\
\text { G } \\
\text { M } \\
\text { M } \\
\text { M } \\
\text { G } \\
\text { G } \\
\text { G } \\
\text { M } \\
\text { P } \\
\text { G } \\
\text { G } \\
\text { M } \\
M\end{array}$ & $\begin{array}{l}\mathrm{F} \\
\mathrm{R} \\
\dot{.} \\
\dot{\mathrm{F}} \\
\mathrm{F} \\
\dot{ }\end{array}$ & $\begin{array}{l}\text { C } \\
\text { C } \\
\text { C } \\
\text { C } \\
\text { C } \\
\text { C } \\
\text { C } \\
\text { C } \\
\text { C } \\
\vdots \\
\therefore \\
\text { C } \\
\therefore\end{array}$ & $\begin{array}{l}\mathrm{F} \\
\mathrm{R} \\
\mathrm{F} \\
\dot{.} \\
\dot{\mathrm{F}} \\
\dot{\mathrm{F}} \\
\mathrm{F} \\
\mathrm{F} \\
\dot{.}\end{array}$ & $\begin{array}{l}\text { F } \\
\dot{F} \\
\dot{F} \\
\dot{.} \\
\dot{\mathrm{F}} \\
\mathrm{F} \\
\dot{.}\end{array}$ & $\begin{array}{l}\dot{\mathrm{F}} \\
\dot{\dot{y}} \\
\dot{\mathrm{F}} \\
\dot{\mathrm{F}} \\
\dot{.}\end{array}$ & $\begin{array}{l}\mathrm{F} \\
\dot{.} \\
\dot{.} \\
\dot{.} \\
\dot{\mathrm{R}} \\
\dot{.} \\
\dot{.}\end{array}$ & $\begin{array}{l}\mathrm{F} \\
\mathrm{F} \\
\dot{\mathrm{F}} \\
\dot{\dot{\mathrm{F}}} \\
\dot{\mathrm{F}} \\
\dot{\mathrm{F}} \\
\dot{\cdot}\end{array}$ & $\begin{array}{l}\dot{.} \\
\mathrm{R} \\
\dot{.} \\
\dot{\mathrm{R}} \\
\dot{\mathrm{R}} \\
\dot{.}\end{array}$ & $\begin{array}{l}\mathrm{R} \\
\dot{\mathrm{F}} \\
\mathrm{F} \\
\dot{\mathrm{R}} \\
\dot{\mathrm{R}} \\
\dot{\mathrm{F}} \\
\dot{\therefore}\end{array}$ & $\begin{array}{c}\mathrm{R} \\
\dot{\cdot} \\
\dot{\cdot} \\
\dot{\mathrm{R}} \\
\dot{\mathrm{F}} \\
\dot{\mathrm{F}} \\
\dot{\mathrm{R}} \\
\dot{\cdot} \\
\dot{\cdot}\end{array}$ & $\begin{array}{l}\dot{.} \\
\dot{.} \\
\dot{\mathrm{F}} \\
\dot{.} \\
\dot{.}\end{array}$ & $\begin{array}{l}\mathrm{F} \\
\mathrm{F} \\
\mathrm{F} \\
\mathrm{F} \\
\dot{\mathrm{F}} \\
\mathrm{F} \\
\mathrm{F} \\
\therefore \\
\therefore\end{array}$ & $\begin{array}{l}\dot{.} \\
\dot{.} \\
\dot{.} \\
\dot{\mathrm{R}} \\
\dot{.} \\
\dot{.}\end{array}$ & $\begin{array}{l}\mathrm{F} \\
\mathrm{F} \\
\mathrm{F} \\
\therefore \\
\therefore \\
\therefore \\
\therefore \\
\therefore\end{array}$ & $\begin{array}{c}\mathrm{R} \\
\mathrm{F} \\
\mathrm{R} \\
\vdots \\
\vdots \\
\vdots \\
\vdots \\
\vdots \\
\vdots \\
\vdots \\
\vdots\end{array}$ & $\begin{array}{l}\mathrm{F} \\
\dot{\mathrm{F}} \\
\dot{ } \\
\dot{.} \\
\dot{.} \\
\dot{.}\end{array}$ & $\begin{array}{l}\dot{R} \\
\dot{y} \\
\dot{y} \\
\dot{y} \\
\dot{y} \\
\dot{y}\end{array}$ & $\begin{array}{l}\dot{\mathrm{F}} \\
\dot{y} \\
\dot{ } \\
\dot{y} \\
\dot{.}\end{array}$ & $\begin{array}{l}\text { C } \\
\dot{y} \\
\therefore \\
\therefore \\
\therefore\end{array}$ & 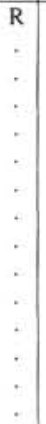 & $\begin{array}{l}\dot{b} \\
\dot{.} \\
\dot{.} \\
\dot{.} \\
\dot{.} \\
\dot{.} \\
\dot{.} \\
\dot{.}\end{array}$ \\
\hline
\end{tabular}

Holotype. UCL-2999-13 (Pl. 2, Fig. 2).

Isotypes. UCL-2999-21 (Pl. 2, Fig. 1); UCL-2999-4 (Pl. 2, Fig. 11): UCL-2999-27 (Pl. 2, Fig. 9).

Type locality. DSDP Site 261, Argo Abyssal Plain, off the northwest shelf of Australia.

Type level. DSDP 27-261-31-2, $129 \mathrm{~cm}$; Berriasian.

Occurrence. DSDP Site 261, Tithonian to Valanginian; DSDP Site 534, Tithonian; Site 765, Valanginian.

Range. Tithonian to Valanginian.

\section{REFERENCES}

Applegate, J. L., Bergen, J. A., Covington, J. M., and Wise, S. S., 1989. Lower Cretaceous calcareous nannofossils from continental margin drill sites off North Carolina (DSDP Leg 93) and Portugal (ODP Leg 103): a comparison. In Crux, J. A., and Van Heck, S. E. (Eds.), Nannofossils and their Applications: Chichester (Ellis Horwood), 212-222.

Bown, P. R., 1987. Taxonomy, evolution, and biostratigraphy of Late Triassic-Early Jurassic calcareous nannofossils. Spec. Pap. Palaeontol., 38:1-118.

Bown, P. R., Cooper, M.K.E., and Lord, A. R., 1988. A calcareous nannofossil biozonation scheme for the early to mid Mesozoic. Newsl. Stratigr., 20:91-114.

Bralower, T. J., 1987. Valanginian to Aptian calcareous nannofossil stratigraphy and correlation with the upper M-sequence magnetic anomalies. Mar. Micropaleontol., 11:293-310.

Bralower, T. J., Monechi, S., and Thierstein, H. R., 1989. Calcareous nannofossil zonation of the Jurassic-Cretaceous boundary interval and correlation with the geomagnetic polarity timescale. Mar. Micropaleontol., 14:153-235.

Cooper, M.K.E., 1985. Nannofossils across the Jurassic-Cretaceous boundary in the Tethyan Realm. In Michelsen, O., and Zeiss, A. (Eds.), Proc. Int. Symp. Jurassic Stratigraphy, 2:429-443. 1989. Nannofossil provincialism in the Late Jurassic-Early Cretaceous (Kimmeridgian to Valanginian) period. In Crux, J. A., and van Heck, S. E. (Eds.), Nannofossils and Their Applications: Chichester (Ellis Horwood), 223-246.

Crux, J. A., 1989. Biostratigraphy and paleogeographical applications of Lower Cretaceous nannofossils from north-western Europe. In Crux, J. A., and van Heck, S. E. (Eds.) Nannofossils and Their Applications: Chichester (Ellis Horwood), 143-211.

Grün, W., and Allemann, F., 1975. The Lower Cretaceous of Caravaca (Spain), Berriasian calcareous nannoplankton of the Miravetes Section (subbetic zone, Prov. of Murcia). Eclogae Geol. Helv., 68:147211.

Jakubowski, M., 1987. A proposed Lower Cretaceous calcareous nannofossil zonation scheme for the Moray Firth area of the North Sea. Abh. Geol. Bundesanst (Austria), 39:99-119.

Ludden, J. N., Gradstein, F. M., et al., 1990. Proc. ODP, Init. Repts., 123: College Station, TX (Ocean Drilling Program).

Moshkovitz, S., and Ehrlich, A., 1987. Watznaueria manivitae Bukrytaxonomic problems and distribution in the Jurassic-Lower Cretaceous sediments of Israel and other Tethyan areas. INA Newsl., 9:110 115.

Mutterlose, J., and Wise, S. W., Jr., 1990. Lower Cretaceous nannofossil biostratigraphy of ODP Leg 113 Holes 692B and 693A, continental slope off East Antarctica, Weddell Sea. In Barker, P. F., Kennett, J. P., et al., Proc. ODP, Sci. Results, 113: College Station, TX (Ocean Drilling Program), 325-351.

Perch-Nielsen, K., 1985. Mesozoic calcareous nannofossils. In Bolli, H. M., Saunders, J. B., and Perch-Nielsen, K. (Eds.), Plankton Stratigraphy: Cambridge (Cambridge Univ. Press), 329-426.

Proto Decima, F., 1974. Leg 27 calcareous nannoplankton. In Veevers, J. J., Heirtzler, J. R., et al., Init. Repts. DSDP, 27: Washington (U.S. Govt. Printing Office), 589-621.

Roth, P. H., 1973. Calcareous nannofossils-Leg 17, Deep Sea Drilling Project. In Winterer, E. L., Ewing, J. I., et al., Init. Repts. DSDP, 17: Washington (U.S. Government Printing Office), 695-795.

1978. Cretaceous nannoplankton biostratigraphy and oceanography of the northwestern Atlantic Ocean. In Benson, W. E., Sheridan, 
R. E., et al., Init. Repts. DSDP. 44: Washington (U.S. Govt. Printing Office), 731-760.

1983. Jurassic and Lower Cretaceous calcareous nannofossils in the western North Atlantic (Site 534): biostratigraphy, preservation and some observations on biogeography and paleoceanography. In Sheridan, R. E., Gradstein, F. M., et al., Init. Repts. DSDP, 76: Washington (U.S. Govt. Printing Office), 587-621.

Roth, P. H., Medd, A. W., and Watkins, D. K., 1983. Jurassic calcareous nannofossil zonation; an overview with new evidence from Deep Sea Drilling Project Site 534A. In Sheridan, R. E., Gradstein, F. M., et al., Init. Repts. DSDP, 76: Washington (U.S. Govt. Printing Office), 573-579.

Wise, S. W., Jr., 1983. Mesozoic and Cenozoic calcareous nannofossils recovered by Deep Sea Drilling Project Leg 71 in the Falkland Plateau region, Southwest Atlantic Ocean. In Ludwig, W. J., Krasheninnikov, V. A., et al., Init. Repts. DSDP, 71 (Pt. 2): Washington (U.S. Govt. Printing Office), 481-550.

1988. Mesozoic-Cenozoic history of calcareous nannofossils in the region of the Southern Ocean. Palaeogeogr., Palaeoclimatol., Palaeoecol., 67:157-179.

Date of initial receipt: 25 March 1991

Date of acceptance: 29 July 1991

Ms 123B-170

\section{ACKNOWLEDGMENTS}

This study was funded by the Natural Environment Research Council. Thanks to Jim Davey and Toby Stiles for laboratory and photographic assistance.

\section{APPENDIX}

List of nannofossil species mentioned in the text, arranged ir. alphabetical order by generic epithets.

Assipetra infracretacea (Thierstein, 1973) Roth (1973)

Axopodorhabdus cylindratus (Noël, 1965) Wind and Wise (1977)

Axopodorhabdus dietzmannii (Reinhardt, 1965) Wind and Wise (1983)

Biscutum dubium (Noël, 1965) Grün in Grün et al. (1974)

Biscutum ellipticum (Gorka, 1957) Grün in Grün and Allemann (1975)

Biscutum erismatum (Wind and Wise, 1977) Grün and Zweili (1980)

Calcicalithina oblongata (Worsley, 1971) Thierstien (1971)

Conusphaera mexicana mexicana Trejo (1969)

Conusphaera mexicana minor (Trejo, 1969) Bown and Cooper (1989)

Crepidolithus perforata (Medd, 1979) Grün and Zweili (1980)

Cretarhabdus conicus Bramlette and Martini (1964)

Crucibiscutum salebrosum (Black, 1971) Jakubowski (1986)

Cruciellipsis cuvillieri (Manivit, 1966) Thierstein, 1971

Cyclagelosphaera argoensis Bown, $\mathrm{n}$. $\mathrm{sp}$.

Cyclagelosphaera margerelii Noël (1965)

Diazomatolithus lehmanii Noël (1965)
Discorhabdus ignotus (Gorka, 1957) Perch-Nielsen (1968)

Eiffellithus windii Applegate and Bergen (1989)

Ethmorhabdus gallicus Noël (1965)

Ethmorhabdus hauterivianus (Black, 1971) Applegate et al. in Covington and Wise (1987)

Grantarhabdus coronadventis (Reinhardt, 1966) Grün in Grün and Allemann (1975)

Haquis circumradiatus (Stover, 1966) Roth (1978)

Haquis ellipticus (Grün in Grün and Allemann, 1975) Bown comb. nov.

Hexapodorhabdus cuvillieri Noël (1965)

Lithraphidites carniolensis Deflandre (1963)

Lotharingius crucicentralis (Medd, 1971) Grün and Zweili (1980)

Manivitella pemmatoidea (Reinhardt, 1966) Thierstein (1977)

Micrantholithus hoschultzi (Reinhardt, 1966) Thierstein (1971)

Micrantholithus obtusus Stradner (1963)

Micrantholithus speetonensis Perch-Nielsen (1979)

Microstaurus chiastius (Worsley, 1971) Grün in Grün and Allemann (1975)

Nannoconus Kamptner (1931)

Pickelhaube furtiva (Roth, 1983) Applegate et al. in Covington and Wise (1987)

Podorhabdus grassei Noël (1965)

Repagulum parvidentatum (Deflandre and Fert, 1954) Forchheimer (1972)

Retecapsa angustiforata Black (1971)

Retecapsa crenulata (Bramlette and Martini, 1964) Grün in Grün and Allemann (1975)

Retecapsa surirella (Deflandre and Fert, 1954) Grün in Grün and Allemann (1975)

Rhagodiscus asper (Stradner, 1963) Reinhardt (1967)

Rhagodiscus nebulosus Bralower in Bralower et al (1989)

Rotelapillus laffittei (Noël, 1957) Noël (1973)

Sollasites Black (1967)

Sollasites arcuatus Black (1971)

Speetonia colligata Black (1971)

Stephanolithion bigotii bigotii Deflandre (1939)

Tegulalithus septentrionalis (Stradner, 1963) Crux (1986)

Tegumentum striatum (Black, 1971) Crux (1989)

Tubodiscus verenae Thierstein (1973)

Vagalapilla matalosa (Stover, 1966) Thierstein (1973)

Vagalapilla stradneri (Rood et al., 1971) Thierstein (1973)

Watznaueria barnesae (Black in Black and Barnes, 1959) PerchNielsen (1968)

Watznaueria biporta Bukry (1969)

Watznaueria britannica (Stradner, 1963) Reinhardt (1964)

Watznaueria fossacincta (Black, 1971) Bown in Bown and Cooper (1990)

Watznaueria manivitae Bukry (1973)

Zeugrhabdotus cooperi Bown, n. sp.

Zeugrhabdotus embergeri (Noël, 1958) Perch-Nielsen (1985)

Zeugrhabdotus erectus (Deflandre, 1954) Reinhardt (1965) 
Table 3. Stratigraphic distribution of calcareous nannofossils from Site 261 (Cores 27-261-34 to -27).

\begin{tabular}{|c|c|c|c|c|c|c|c|c|c|c|c|c|c|c|c|c|c|c|c|c|c|c|c|c|c|}
\hline Age & Sample & 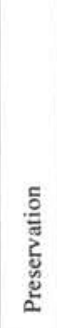 & 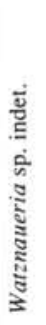 & 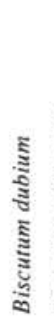 & 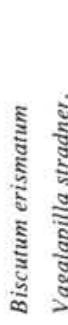 & 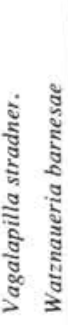 & $\begin{array}{c}3 \\
3 \\
3\end{array}$ & 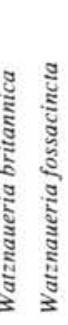 & 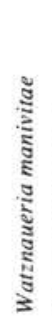 & 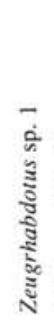 & 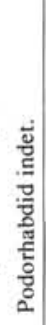 & 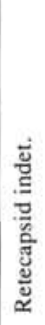 & 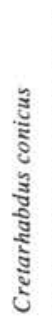 & 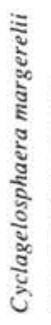 & & 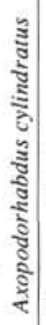 & 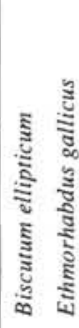 & 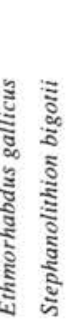 & 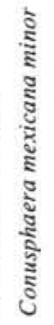 & 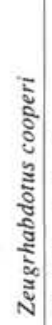 & 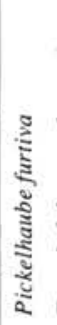 & 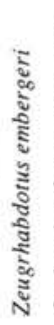 & 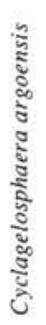 & 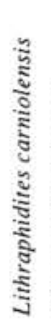 & 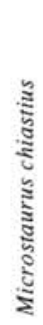 \\
\hline $\begin{array}{c}\text { late } \\
\text { Valanginian- } \\
\text { Hauterivian }\end{array}$ & $\begin{array}{l}27-1,140 \\
27-2,57 \\
27-2,71 \\
27-2,109 \\
27-2,142 \\
28-1,70 \\
28-1,71 \\
28-1,99 \\
28-1,145 \\
28-2,07 \\
28-2,59 \\
28-2,112 \\
28-2,121\end{array}$ & $\begin{array}{c}\mathrm{P} \\
\mathrm{P} \\
\mathrm{P} \\
\mathrm{M} \\
\mathrm{P}\end{array}$ & $\begin{array}{l}\mathrm{F} \\
\dot{\mathrm{F}} \\
\dot{\mathrm{C}} \\
\dot{\mathrm{C}} \\
\dot{\cdot} \\
\dot{\cdot}\end{array}$ & $\begin{array}{l}: \\
: \\
\vdots \\
:\end{array}$ & $::$ & $\begin{array}{l}\mathrm{R} \\
\mathrm{R} \\
\mathrm{R} \\
\mathrm{R} \\
\mathrm{R} \\
\mathrm{C} \\
\mathrm{A} \\
\mathrm{A}\end{array}$ & $\begin{array}{l}: \\
\text { R } \\
\mathrm{R} \\
\mathrm{R} \\
\mathrm{Z} \\
\end{array}$ & 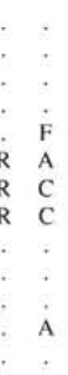 & $\begin{array}{l}: \\
\therefore \\
\therefore \\
\therefore\end{array}$ & $\begin{array}{l}: \\
\therefore \\
\therefore\end{array}$ & $\begin{array}{l}: \\
: \\
: \\
: \\
: \\
: \\
: \\
: \\
:\end{array}$ & $\begin{array}{l}\dot{:} \\
\dot{\mathrm{F}} \\
\mathrm{R} \\
\dot{\mathrm{R}} \\
\dot{\mathrm{R}} \\
\dot{\mathrm{C}}\end{array}$ & $\begin{array}{l}: \\
: \\
: \\
:\end{array}$ & $\begin{array}{l}\mathrm{R} \\
\mathrm{R} \\
\mathrm{R} \\
\mathrm{R} \\
\dot{.} \\
\dot{\mathrm{F}} \\
\dot{.}\end{array}$ & $\begin{array}{l}: \\
: \\
\text { R }\end{array}$ & $\begin{array}{l}: \\
: \\
: \\
:\end{array}$ & $\begin{array}{c}\vdots \\
\vdots \\
\vdots \\
\vdots \\
\vdots\end{array}$ & $:$ & $\begin{array}{l}: \\
: \\
: \\
: \\
: \\
:\end{array}$ & $\begin{array}{l}\vdots \\
\vdots \\
\vdots \\
\vdots \\
\vdots \\
\vdots\end{array}$ & $\begin{array}{l}\dot{.} \\
\dot{.} \\
\dot{.} \\
\dot{\mathrm{R}}\end{array}$ & $\begin{array}{l}\dot{:} \\
\dot{\mathrm{R}} \\
\mathrm{F} \\
\mathrm{R} \\
\mathrm{R} \\
\dot{2} \\
\dot{\mathrm{C}} \\
\dot{\mathrm{C}}\end{array}$ & $\begin{array}{l}: \\
: \\
: \\
:\end{array}$ & $\begin{array}{l}\vdots \\
\vdots \\
\therefore \\
\text { R } \\
\therefore\end{array}$ & $\begin{array}{l}\dot{5} \\
\dot{5} \\
\dot{5} \\
\dot{5} \\
\dot{5} \\
\dot{.}\end{array}$ \\
\hline Valanginian & $\begin{array}{l}-2,128 \\
-3,48 \\
-3,103 \\
-3,110 \\
-4,10 \\
-1,134 \\
-1,140 \\
-2,38 \\
-2,80 \\
-3,30\end{array}$ & $\begin{array}{c}\mathrm{P} \\
\mathrm{P} \\
\mathrm{VP} \\
\mathrm{P} \\
\mathrm{P} \\
\mathrm{P} \\
\mathrm{M} \\
\mathrm{P} \\
\mathrm{M}\end{array}$ & $\begin{array}{l}\text { : } \\
\text { C } \\
\text { C } \\
:\end{array}$ & $\begin{array}{l}\vdots \\
\vdots \\
\vdots \\
\vdots\end{array}$ & $\begin{array}{l}: \\
:\end{array}$ & $\begin{array}{l}\mathrm{C} \\
\vdots \\
\mathrm{R} \\
\vdots \\
\mathrm{R} \\
\mathrm{R} \\
\mathrm{R} \\
\mathrm{R} \\
\mathrm{R}\end{array}$ & $\begin{array}{l}\mathrm{R} \\
\mathrm{R} \\
\mathrm{R} \\
\\
\\
\mathrm{R} \\
\mathrm{R} \\
\mathrm{R} \\
\mathrm{R}\end{array}$ & $\begin{array}{cc}\mathrm{R} & \mathrm{A} \\
& \dot{\mathrm{C}} \\
\mathrm{R} & \mathrm{C} \\
\mathrm{B} & \mathrm{A} \\
\mathrm{A} & \mathrm{A} \\
\mathrm{R} & \mathrm{A} \\
\mathrm{R} & \mathrm{A} \\
\mathrm{R} & \mathrm{A} \\
\mathrm{F} & \mathrm{A}\end{array}$ & $\begin{array}{l}: \\
\vdots \\
\vdots\end{array}$ & $\begin{array}{l}\vdots \\
\vdots \\
\vdots \\
\vdots\end{array}$ & $\begin{array}{c} \\
\dot{\mathrm{R}} \\
\dot{\vdots} \\
\vdots \\
\dot{\mathrm{R}} \\
\dot{ } \\
\dot{ }\end{array}$ & $\begin{array}{l}\dot{ } \\
\vdots \\
\dot{\mathrm{F}} \\
\mathrm{F} \\
\mathrm{F} \\
\mathrm{F} \\
\dot{\mathrm{C}} \\
\mathrm{C} \\
\dot{\mathrm{C}} \\
\mathrm{C}\end{array}$ & $\begin{array}{l}\mathrm{R} \\
\vdots \\
\vdots \\
\vdots \\
\vdots \\
\vdots \\
\vdots \\
\dot{\mathrm{R}}\end{array}$ & $\begin{array}{l}\mathrm{C} \\
\vdots \\
\mathrm{V}\end{array}$ & $\begin{array}{l}\mathrm{F} \\
\\
8 \\
\end{array}$ & $\begin{array}{l}\dot{ } \\
\vdots \\
\vdots \\
\vdots\end{array}$ & $\begin{array}{c}\mathrm{R} \\
\\
\vdots \\
\vdots \\
\vdots \\
\vdots \\
\vdots\end{array}$ & $:$ & $\begin{array}{l}: \\
: \\
\vdots \\
\vdots \\
\vdots \\
:\end{array}$ & $\begin{array}{l} \\
\vdots \\
\vdots \\
\vdots \\
\vdots \\
\vdots \\
\vdots \\
\end{array}$ & $\begin{array}{c}\mathrm{R} \\
\vdots \\
\dot{\mathrm{R}} \\
\dot{\mathrm{R}} \\
\dot{\vdots} \\
\dot{\mathrm{R}} \\
\dot{\mathrm{R}} \\
\mathrm{R}\end{array}$ & $\begin{array}{l}\mathrm{C} \\
\dot{R} \\
\mathrm{R} \\
\dot{R} \\
\dot{R} \\
\mathrm{R} \\
\dot{R} \\
\mathrm{R} \\
\dot{\mathrm{F}} \\
\mathrm{F}\end{array}$ & $\begin{array}{l}: \\
: \\
\dot{R} \\
\dot{\mathrm{R}} \\
\dot{\mathrm{F}}\end{array}$ & $\begin{array}{l}\mathrm{C} \\
\vdots \\
\vdots \\
\vdots \\
\vdots \\
\dot{\mathrm{R}}\end{array}$ & $\begin{array}{l}\mathrm{F} \\
\vdots \\
\vdots \\
\vdots \\
\mathrm{R} \\
\dot{\mathrm{R}}\end{array}$ \\
\hline Berriasian & $\begin{array}{l}-2,130 \\
-3,90 \\
-3,140 \\
-4,20 \\
-4,140 \\
-2,40 \\
-2,80 \\
-2,122 \\
-2,129 \\
-3,10 \\
-3,40\end{array}$ & $\begin{array}{c}M \\
\text { VP } \\
G \\
P \\
\text { VP }\end{array}$ & $\begin{array}{l}\vdots \\
\vdots \\
\vdots\end{array}$ & $\begin{array}{l}: \\
: \\
:\end{array}$ & $\begin{array}{l}: \\
\vdots \\
\vdots\end{array}$ & $\begin{array}{l}\mathrm{B} \\
\mathrm{R} \\
\dot{\mathrm{C}} \\
\mathrm{R} \\
\mathrm{R}\end{array}$ & $\begin{array}{l}\mathrm{F} \\
\mathrm{R} \\
\mathrm{R} \\
\\
\\
\mathrm{F} \\
\mathrm{R} \\
\mathrm{F} \\
\mathrm{R}\end{array}$ & $\begin{array}{ll}\mathrm{F} & \mathrm{A} \\
\mathrm{C} & \mathrm{C} \\
\mathrm{R} & \mathrm{A} \\
\mathrm{R} & \mathrm{A} \\
\cdot & \mathrm{F} \\
\mathrm{F} & \cdot \\
\mathrm{F} & \mathrm{A} \\
\mathrm{R} & \mathrm{A} \\
\mathrm{F} & \mathrm{A} \\
\mathrm{R} & \mathrm{A}\end{array}$ & : & : & $\begin{array}{l}: \\
: \\
: \\
: \\
: \\
:\end{array}$ & $\begin{array}{l}\mathrm{C} \\
\mathrm{F} \\
\dot{ } \\
\dot{\mathrm{F}} \\
\mathrm{R} \\
\mathrm{F} \\
\mathrm{F}\end{array}$ & $\begin{array}{l}\vdots \\
\vdots \\
\vdots \\
\vdots \\
\vdots\end{array}$ & $\begin{array}{l}\mathrm{F} \\
\dot{R} \\
\mathrm{R} \\
\dot{C} \\
\dot{C} \\
\mathrm{C} \\
\mathrm{R} \\
\mathrm{F} \\
\mathrm{R}\end{array}$ & $\begin{array}{l}\mathrm{R} \\
\mathrm{R} \\
\mathrm{R} \\
\mathrm{R}\end{array}$ & $\begin{array}{l}: \\
\vdots \\
\vdots\end{array}$ & $\begin{array}{l}\mathrm{R} \\
\mathrm{F} \\
\mathrm{F}\end{array}$ & $\begin{array}{l}\cdot \\
\vdots \\
\vdots \\
\vdots\end{array}$ & $\begin{array}{l}\dot{ } \\
\vdots \\
\vdots \\
\vdots \\
\dot{ }\end{array}$ & \begin{tabular}{c|}
$\dot{R}$ \\
$\mathrm{R}$ \\
$\dot{y}$ \\
$\dot{y}$ \\
$\dot{\mathrm{A}}$ \\
$\mathrm{A}$ \\
$\mathrm{C}$ \\
$\mathrm{F}$
\end{tabular} & $\begin{array}{l}\mathrm{R} \\
\mathrm{R} \\
\vdots \\
\vdots \\
\vdots \\
\dot{\cdot}\end{array}$ & $\begin{array}{l}\mathrm{F} \\
\mathrm{R} \\
\mathrm{R} \\
\mathrm{F} \\
\dot{5} \\
\dot{\mathrm{R}} \\
\dot{\mathrm{R}} \\
\dot{\cdot}\end{array}$ & $\begin{array}{l}\mathrm{F} \\
\dot{\mathrm{R}} \\
\mathrm{C} \\
\mathrm{R} \\
\dot{.} \\
\dot{\mathrm{F}} \\
\mathrm{R} \\
\mathrm{R} \\
\mathrm{R}\end{array}$ & $\begin{array}{l}\vdots \\
\vdots \\
\dot{ } \\
\dot{ }\end{array}$ & $\begin{array}{l}\mathrm{R} \\
\mathrm{R} \\
\vdots \\
\dot{\mathrm{R}} \\
\mathrm{R} \\
\dot{ } \\
\dot{\mathrm{R}}\end{array}$ \\
\hline Tithonian & $\begin{array}{l}l, \\
C C \\
1,136 \\
1,140 \\
2,10 \\
2,40 \\
2,64 \\
2,69 \\
2,70 \\
2,100 \\
2,140 \\
3,10 \\
3,40 \\
3,70\end{array}$ & $\begin{array}{c}\mathrm{G} \\
\mathrm{M} \\
\mathrm{VP} \\
\mathrm{P} \\
\mathrm{VP}\end{array}$ & i & $\begin{array}{l}: \\
\vdots \\
\vdots \\
\vdots \\
: \\
: \\
: \\
: \\
:\end{array}$ & $\begin{array}{l}5 \\
:\end{array}$ & 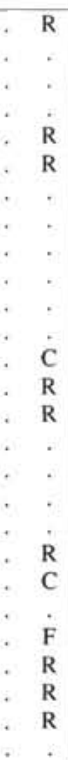 & $\begin{array}{l}\mathrm{R} \\
\\
\mathrm{R} \\
\mathrm{R} \\
\\
\\
\\
\mathrm{C} \\
\mathrm{R} \\
\\
\\
\\
\mathrm{R} \\
\mathrm{R} \\
\mathrm{R} \\
\\
\\
\mathrm{R}\end{array}$ & 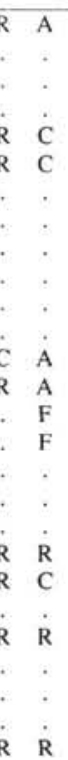 & $\begin{array}{l} \\
\vdots \\
\text { R } \\
\mathrm{R} \\
\vdots \\
\vdots \\
\dot{R} \\
\mathrm{R} \\
\mathrm{R} \\
\mathrm{R} \\
\mathrm{R} \\
\end{array}$ & 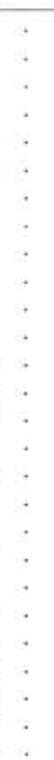 & $\begin{array}{l}: \\
: \\
: \\
\vdots \\
\vdots \\
: \\
: \\
: \\
: \\
: \\
: \\
: \\
:\end{array}$ & $\begin{array}{l}\mathrm{R} \\
\vdots \\
\mathrm{R} \\
\vdots \\
\vdots \\
\vdots\end{array}$ & $\begin{array}{l}\dot{5} \\
\vdots \\
\vdots \\
\vdots \\
\vdots \\
\vdots \\
\vdots\end{array}$ & $\begin{array}{l}\mathrm{R} \\
\vdots \\
\dot{\mathrm{R}} \\
\mathrm{R} \\
\vdots \\
\vdots \\
\mathrm{A} \\
\mathrm{R} \\
\dot{\mathrm{A}} \\
\vdots\end{array}$ & $\begin{array}{l}: \\
\vdots \\
\vdots \\
\vdots\end{array}$ & $\begin{array}{l}\dot{0} \\
\vdots \\
\vdots \\
\vdots \\
\vdots\end{array}$ & $\begin{array}{l}\mathrm{R} \\
\\
\vdots \\
\vdots\end{array}$ & 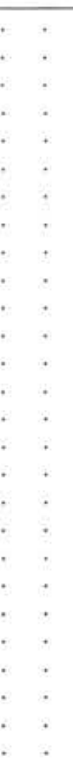 & $\begin{array}{l}: \\
\vdots \\
\vdots\end{array}$ & \begin{tabular}{c|c}
$\mathrm{R}$ & \\
& \\
$\mathrm{F}$ & $\mathrm{R}$ \\
$\vdots$ & \\
$\vdots$ & \\
$\mathrm{F}$ & $\mathrm{R}$ \\
$\dot{\mathrm{R}}$ & \\
$\vdots$ & \\
$\vdots$ & \\
$\vdots$ & \\
\end{tabular} & $\begin{array}{l} \\
\\
\vdots \\
\vdots \\
\vdots \\
\vdots \\
\vdots \\
\vdots \\
\vdots \\
\vdots \\
\vdots \\
\vdots \\
\vdots \\
\\
\end{array}$ & $\begin{array}{l}\mathrm{R} \\
\mathrm{R} \\
\vdots \\
\mathrm{F} \\
\mathrm{R}\end{array}$ & $\begin{array}{l}\mathrm{R} \\
\vdots \\
\mathrm{R} \\
\mathrm{F} \\
\dot{ } \\
\dot{\mathrm{C}} \\
\dot{\mathrm{C}}\end{array}$ & $\begin{array}{l}\vdots \\
\vdots \\
\vdots \\
\mathrm{R} \\
\vdots \\
\vdots\end{array}$ & $\begin{array}{l}\vdots \\
\vdots \\
\vdots \\
\vdots \\
\vdots \\
\mathrm{R} \\
\vdots \\
\vdots \\
\vdots \\
:\end{array}$ \\
\hline
\end{tabular}


Table 3 (continued).

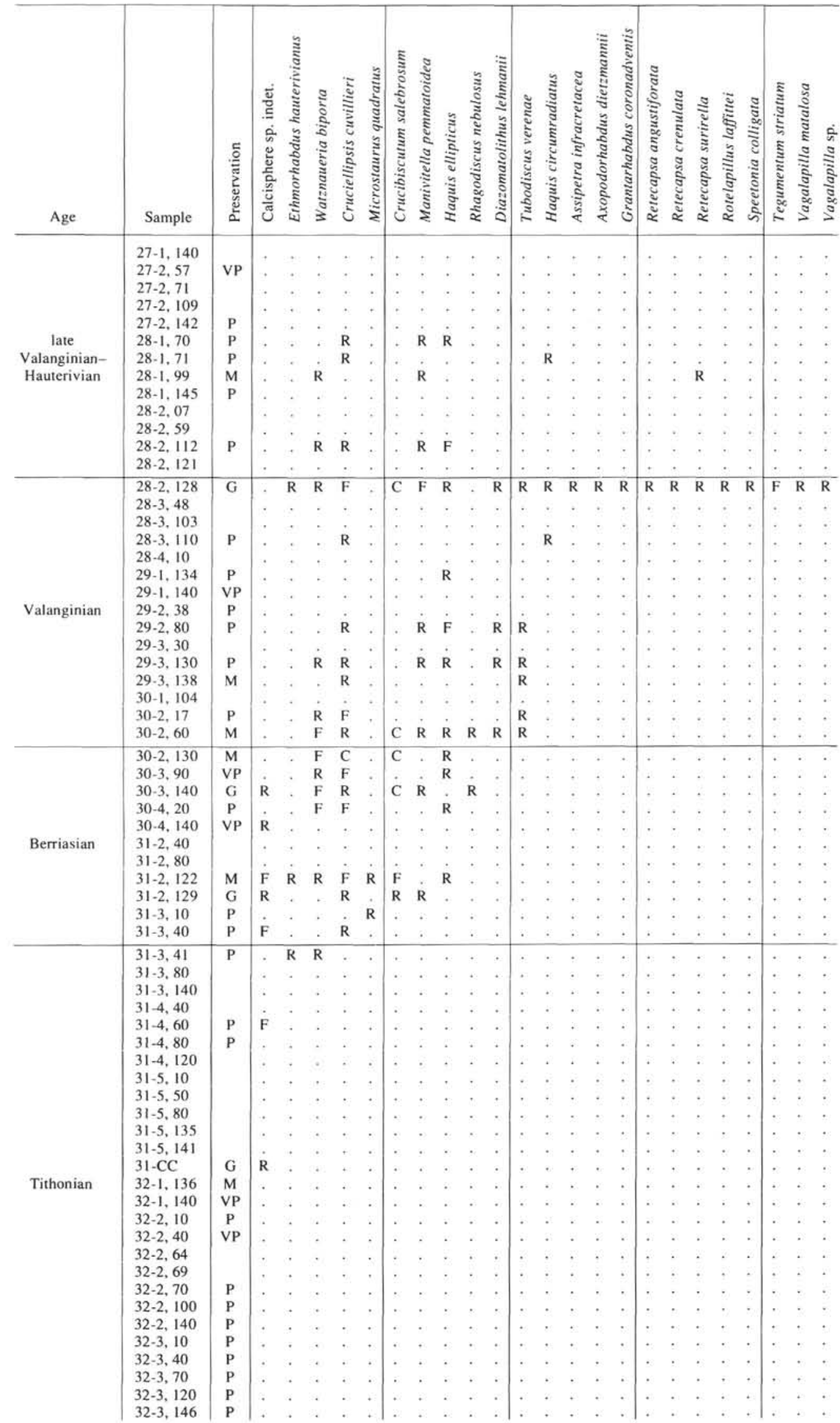


Table 3 (continued).

\begin{tabular}{|c|c|c|c|c|c|c|c|c|c|c|c|c|c|c|c|c|c|c|c|c|c|c|}
\hline Age & Sample & 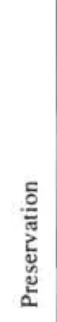 & 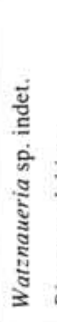 & 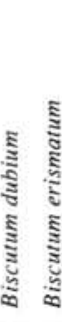 & 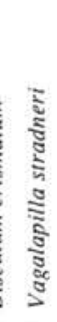 & 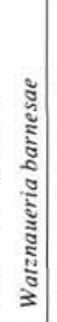 & 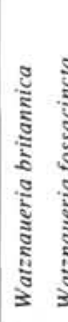 & 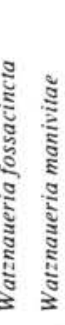 & 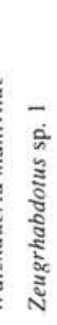 & 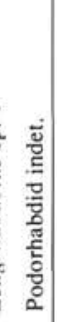 & 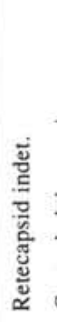 & 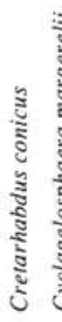 & 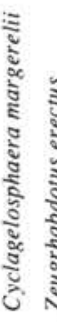 & 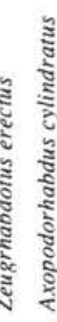 & 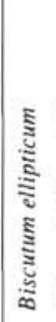 & 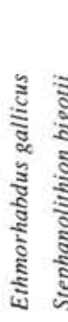 & 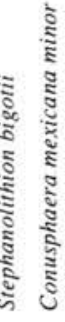 & 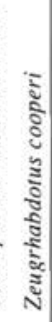 & 离 & 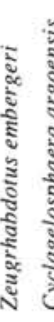 & 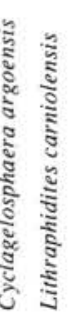 & 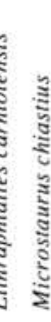 \\
\hline Tithoni & $\begin{array}{l}140 \\
. C \\
.01 \\
.05\end{array}$ & $\begin{array}{l}\text { VP } \\
P \\
P \\
P \\
P \\
P \\
M \\
G \\
G\end{array}$ & $:$ & $\begin{array}{l} \\
\\
R \\
R\end{array}$ & : & \begin{tabular}{l|}
$\mathrm{R}$ \\
$\mathrm{R}$ \\
$\mathrm{R}$ \\
$\mathrm{C}$ \\
$\mathrm{F}$ \\
$\mathrm{C}$ \\
$\mathrm{C}$ \\
$\mathrm{A}$
\end{tabular} & $\begin{array}{ll}\mathrm{F} & \\
\mathrm{C} & \mathrm{R} \\
\mathrm{R} & \mathrm{R} \\
\mathrm{A} & \\
\mathrm{F} & \mathrm{F} \\
\mathrm{C} & \mathrm{C} \\
\mathrm{C} & \mathrm{C} \\
\mathrm{C} & \mathrm{C}\end{array}$ & 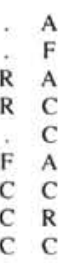 & $\begin{array}{l}: \\
\dot{\mathrm{R}} \\
\mathrm{F}\end{array}$ & $\begin{array}{l} \\
\vdots \\
\mathrm{R} \\
\mathrm{F}\end{array}$ & $\begin{array}{l} \\
\mathrm{F} \\
\mathrm{R} \\
\mathrm{R} \\
\mathrm{R}\end{array}$ & 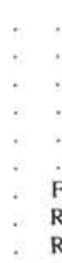 & $\begin{array}{ll} \\
\\
\end{array}$ & : & R. & 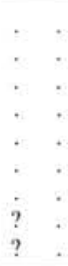 & $\begin{array}{l}\mathrm{R} \\
\mathrm{R} \\
\mathrm{R} \\
\mathrm{R}\end{array}$ & $\begin{array}{l} \\
\dot{\mathrm{R}}\end{array}$ & $\begin{array}{l}\text { R } \\
:\end{array}$ & : & $:$ & : \\
\hline $\begin{array}{l}\text { 1. Kimm.- } \\
\text { e. Tith. }\end{array}$ & $\begin{array}{l}33-1,10 \\
33-1,15 \\
33-1,19 \\
33-1,25 \\
33-1,59\end{array}$ & $\begin{array}{c}\mathrm{G} \\
\mathrm{G} \\
\mathrm{G} \\
\mathrm{M} \\
\mathrm{P}\end{array}$ & $\mathrm{F}$ & $\begin{array}{ll} & R \\
R & R \\
ن & R \\
R & R \\
& \end{array}$ & $\begin{array}{l}\mathrm{R} \\
\mathrm{R} \\
\dot{\mathrm{R}} \\
\dot{\mathrm{m}}\end{array}$ & $\begin{array}{l}\mathrm{A} \\
\mathrm{A} \\
\mathrm{A} \\
\mathrm{C}\end{array}$ & $\begin{array}{ll}\mathrm{C} & \mathrm{C} \\
\mathrm{A} & \mathrm{C} \\
\mathrm{C} & \mathrm{C} \\
\mathrm{C} & \mathrm{F} \\
\mathrm{C} & \end{array}$ & $\begin{array}{ll}\mathrm{C} & \mathrm{C} \\
\mathrm{C} & \mathrm{C} \\
\mathrm{C} & \mathrm{C} \\
\mathrm{F} & \mathrm{F} \\
& \end{array}$ & $\begin{array}{l}\mathrm{R} \\
\mathrm{C} \\
\mathrm{F} \\
\mathrm{R}\end{array}$ & $\begin{array}{l}\mathrm{F} \\
\mathrm{F} \\
\mathrm{F} \\
\mathrm{R} \\
\end{array}$ & $\begin{array}{l}\mathrm{F} \\
\mathrm{C} \\
\mathrm{R} \\
\mathrm{R} \\
\text {. }\end{array}$ & $\begin{array}{ll}\mathrm{R} & \mathrm{R} \\
\mathrm{R} & \mathrm{F} \\
\mathrm{R} & \mathrm{R} \\
& \mathrm{V} \\
& \end{array}$ & $\begin{array}{ll}\mathrm{R} & \mathrm{R} \\
\mathrm{F} & \mathrm{F} \\
\mathrm{R} & \mathrm{R} \\
\cdot & \\
& \end{array}$ & $\begin{array}{l}? \\
? \\
? \\
?\end{array}$ & $\begin{array}{l}\text { R } \\
. \\
.\end{array}$ & $\begin{array}{ll} & \mathbf{R} \\
? & \mathrm{R} \\
\vdots & \\
\vdots & \end{array}$ & $\begin{array}{ll}\mathbf{R} & \mathbf{R} \\
\mathbf{R} & : \\
\vdots & \vdots \\
\vdots & \vdots\end{array}$ & : & $:$ & : & $:$ & : \\
\hline
\end{tabular}

Table 3 (continued).

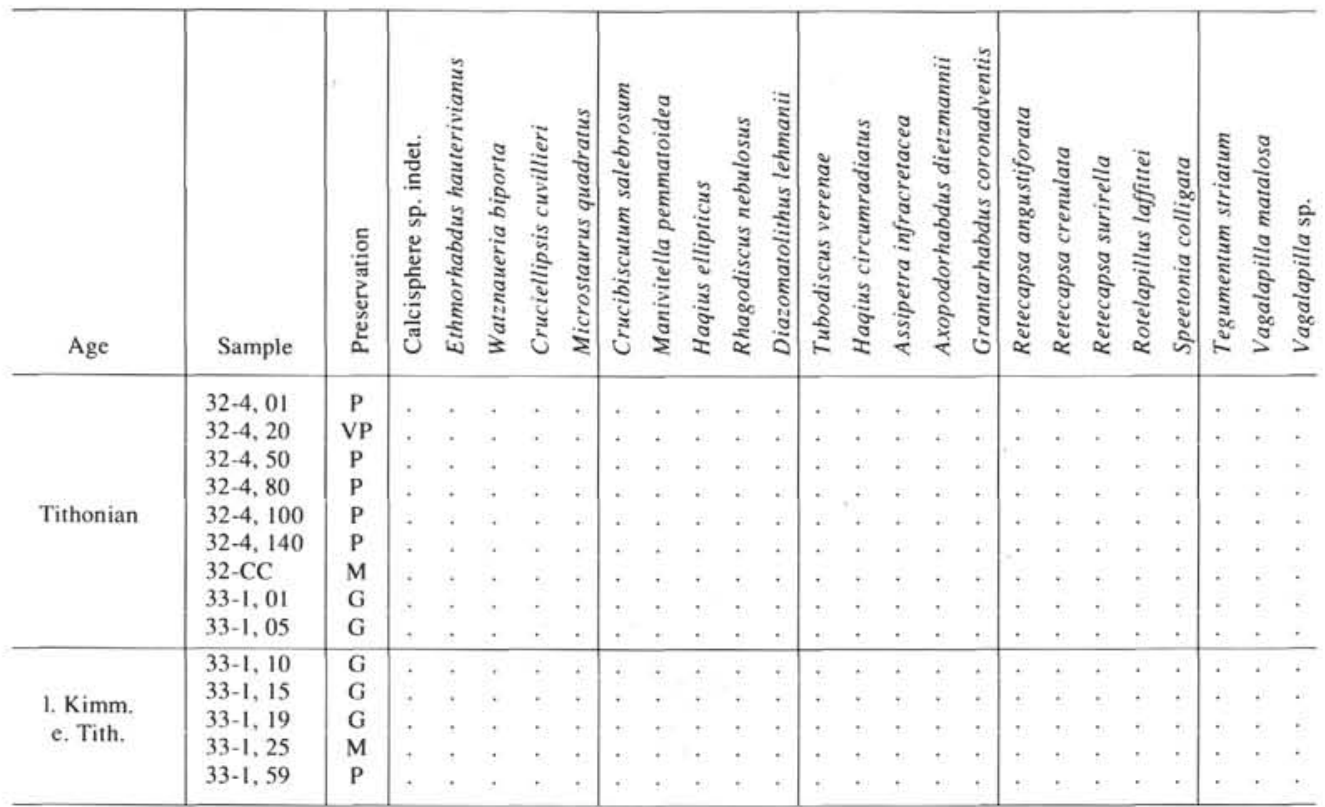



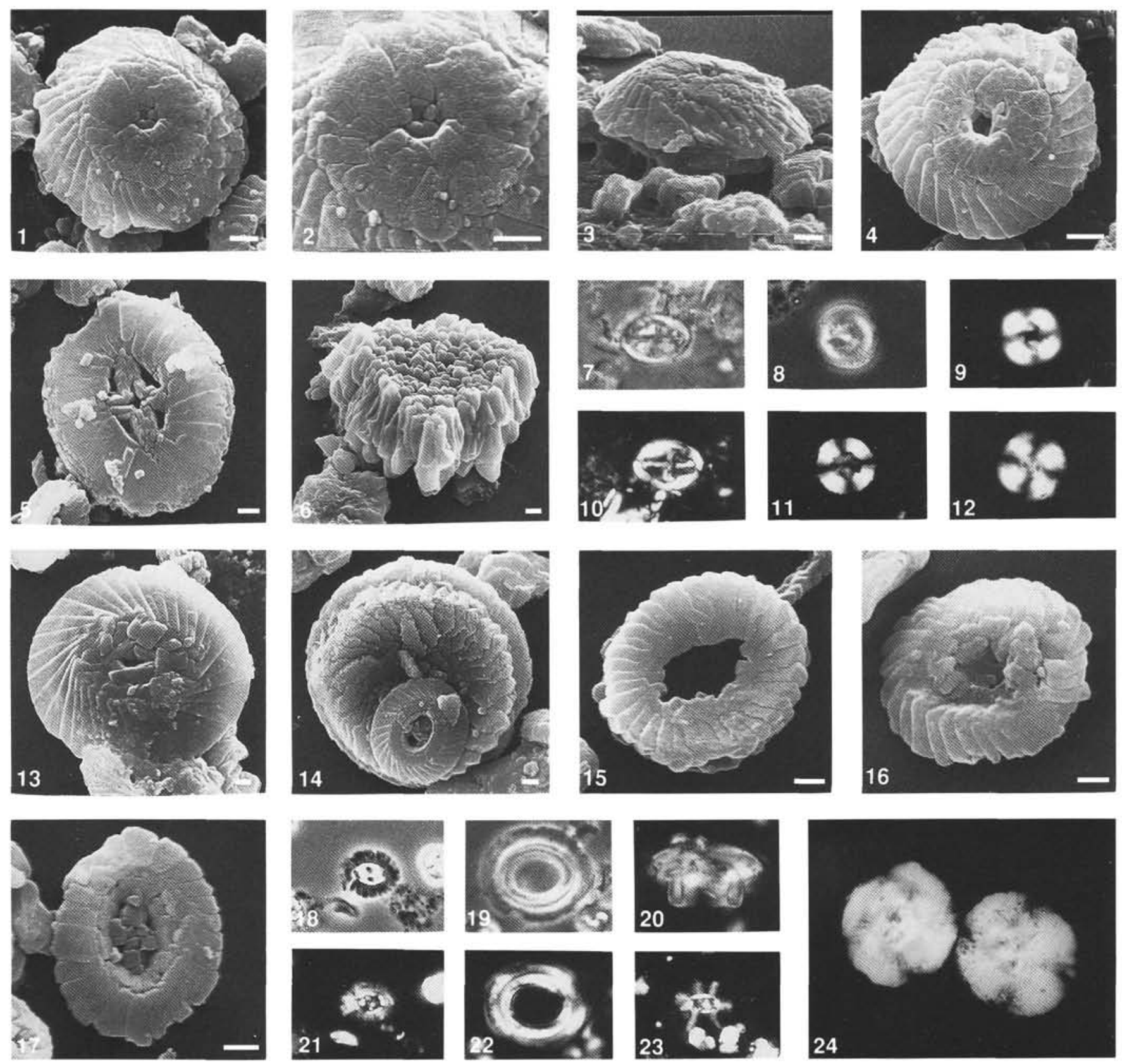

Plate 1. 1-4, 8, 9, 11, 12. Cyclagelosphaera argoensis sp. nov. 1. Holotype SEM distal view; Sample 27-261-31, CC; UCL-2999-33, 2. SEM inner cycle enlargement (1.1); UCL-2999-32. 3. SEM oblique view (1.1); UCL-2999-34. 4. Isotype SEM distal view; sample 27-261-31-CC; UCL-2999-28. 8. LM P-C; Sample 27-261-30-4, 20 cm; UCL-2948-23. 11. LM X-P (1.9); UCL-2948-21. 9. LM X-P; Sample 27-261-30-4, 20 cm; UCL-2948-22. 12. LM X-P; Sample 27-261-30-2, $130 \mathrm{~cm}$; UCL-2984-13. 5. Cruciellipsis cuvillieri (Manivit) Thierstein, SEM distal view; Sample 27-261-28-2, 128 cm; UCL-3000-21. 6. Calcisphere fragment, SEM; Sample 123-765C-61R-4, $21 \mathrm{~cm}$; UCL-3000-20. 7, 10. Vagalapilla matalosa (Stover) Thierstein. 7. LM P-C, Sample 123-765C-55R-3, 119 cm; UCL-3369-13. 10. LM X-P (1.7); UCL-3369-12. 13-16, 24. Watznaueria manivitae Bukry. 13. SEM distal view; Sample 27-261-33-1, $10 \mathrm{~cm}$; UCL-3000-33. 14. SEM proximal view (with $W$. britannica); Sample 27-261-33-1, 10 cm; UCL-3000-28. 15. SEM proximal view, etched specimen; Sample 123-765C-61R-4, $21 \mathrm{~cm}$; UCL-3000-16. 16. SEM distal view, etched specimen; Sample 123-756C-61R-4, 21 cm; UCL-3000-17. 24. LM X-P; Sample 27-261-32-3, 10 cm; UCL-2948-28, 17, 18, 21. Crucibiscutum salebrosum (Black) Jakubowski. 17. SEM distal view; Sample 27-261-30-3, 140 cm; UCL-3000-9. 18. LM P-C; Sample 27-261-30-2, 130 cm; UCL-2948-18. 21. LM X-P (1.18); UCL-2948-17. 19, 20, 22. Tubodiscus verenae Thierstein. 19. LM P-C; Sample 27-261-28-2, $128 \mathrm{~cm}$; UCL-2955-15; 20. LM X-P side view; Sample 27-261-28-2, 128 cm; UCL-2996-14; 22. LM X-P (1.19); UCL-2955-14. 23. Stephanolithion bigotii Deflandre; LM X-P; Sample 27-261-33-1, 15 cm; UCL-2948-35. Note: Abbreviations used in plate descriptions: $\mathrm{SEM}=$ scanning electron micrograph; $\mathrm{LM}=$ light micrograph; $\mathrm{P}-\mathrm{C}=\mathrm{phase}$ contrast; $\mathrm{X}-\mathrm{P}=$ cross-polarized. 

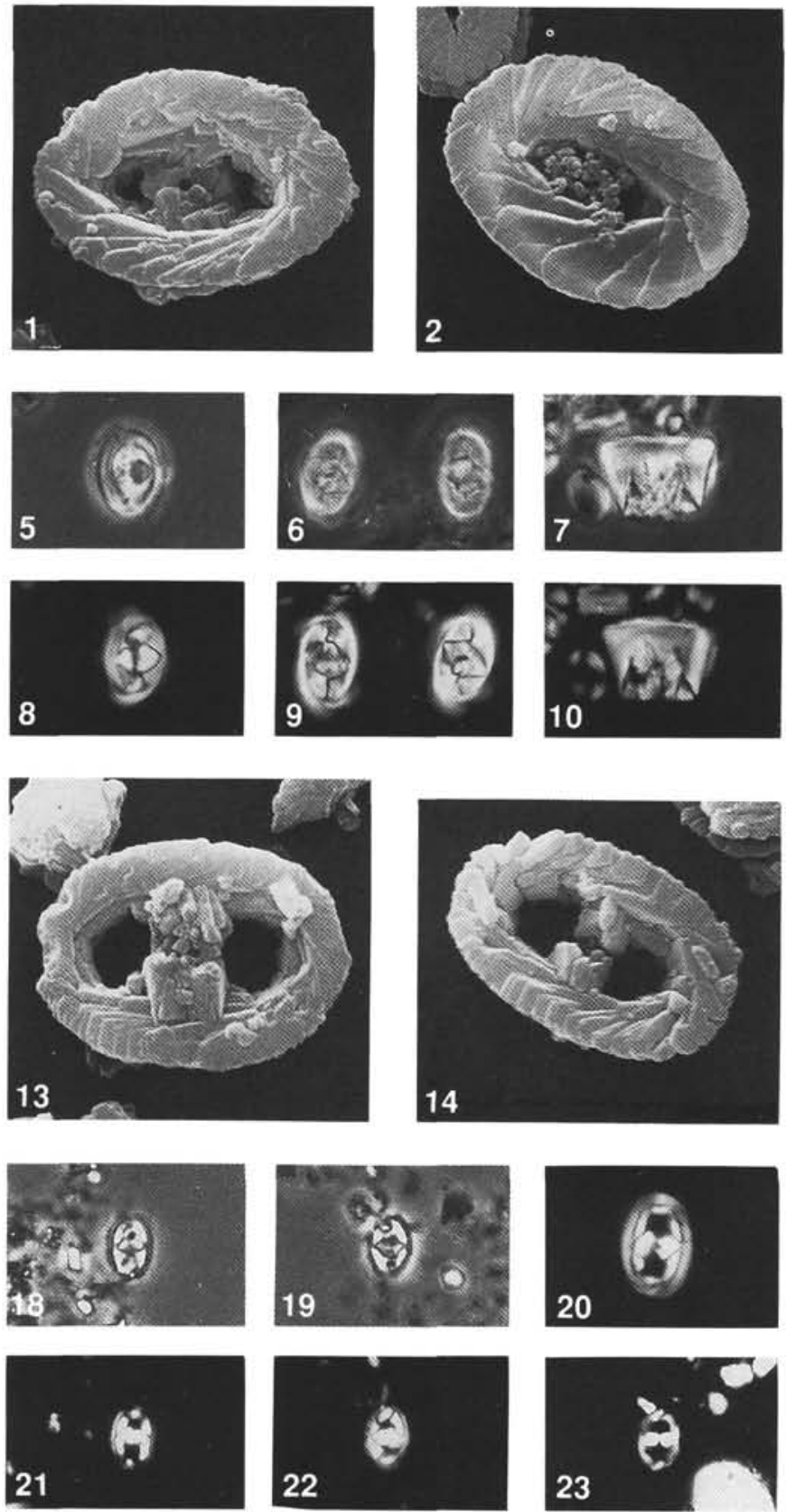
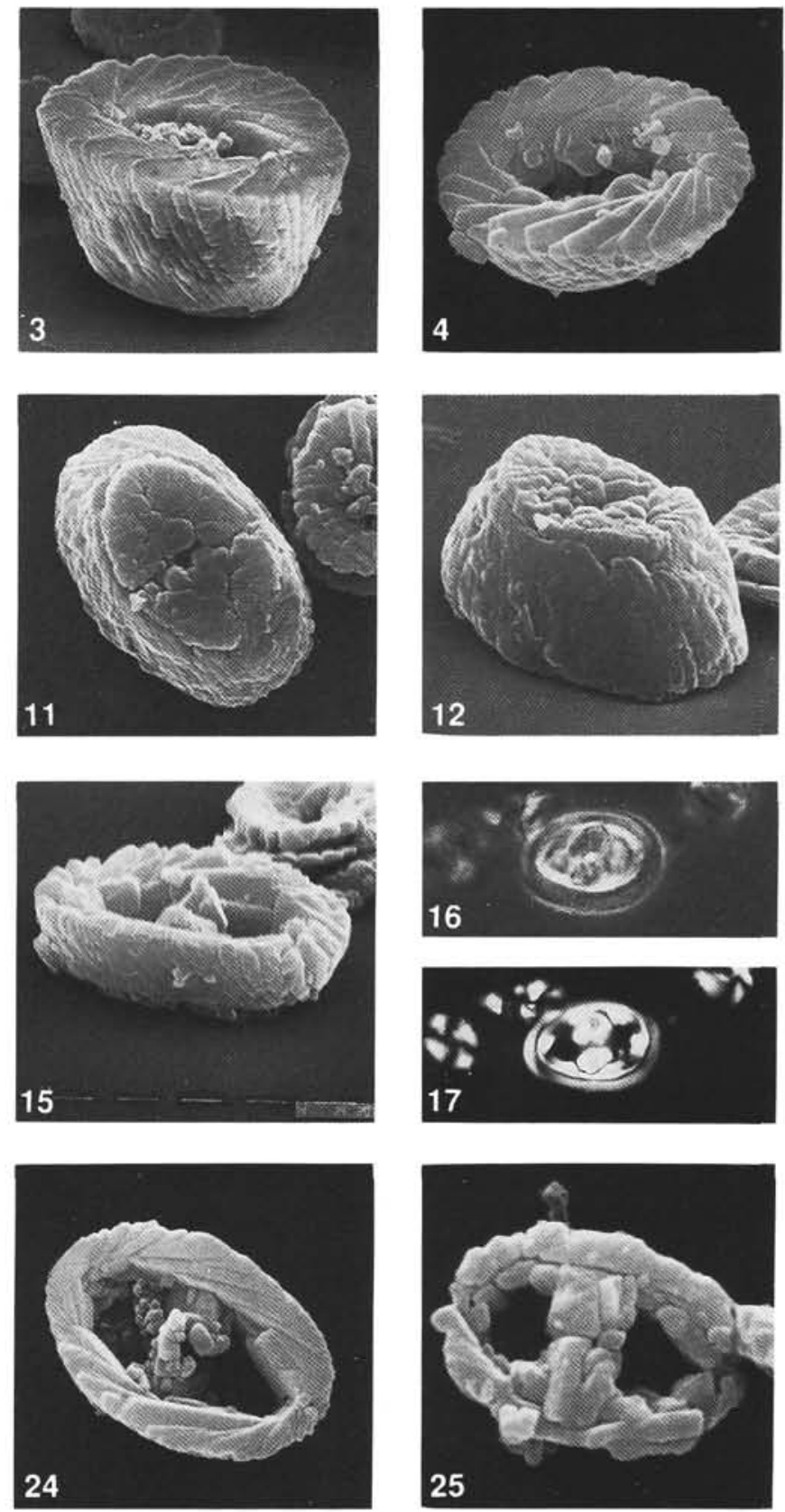

Plate 2. 1-12. Zeugrhabdotus cooperi sp. nov.; Sample 27-261-31-2, $129 \mathrm{~cm}$. 1. Isotype SEM distal view; UCL-2999-21. 2. Holotype SEM distal view; UCL-2999-13. 3. SEM side view (2.2); UCL-2999-14. 4. SEM distal view; UCL-2999-12. 11. Isotype SEM proximal view; UCL-2999-4. 12. SEM side view (2.11); UCL-2999-5. 5. LM P-C; UCL-2996-22. 8. LM X-P (2.5); UCL-2996-21. 6. LM P-C; UCL-2996-30. 9. LM X-P (2.6); UCL-2996-27. 7. LM P-C (side view); Sample 27-261-31-2. 122; UCL-2996-34. 10. LM X-P (2.7); UCL-2996-30. 13-17, 20. Zeugrhabdotus embergeri (Noël) Perch-Nielsen. 13. SEM distal view; Sample 27-261-28-2, $128 \mathrm{~cm}$; UCL-3000-25; 14. SEM distal view; Sample 27-261-30-3, 140 cm; UCL-3000-7. 15. SEM side view (2.14); UCL-3000-8. 16. LM P-C; Sample 27-261-28-2, $128 \mathrm{~cm}$; UCL-2955-23. 17. LM X-P (2.16); UCL-2955-22. 20. LM X-P, Sample 27-261-28-2, $112 \mathrm{~cm}$; UCL-2948-3. 18, 19, 21, 22, 25. Zeugrhabdotus sp. 1. 18. LM P-C; Sample 27-261-33-1, 15 cm; UCL-2948-30. 21. LM X-P (2.18); UCL-2948-29. 19. LM P-C; Sample 27-261-33-1, $15 \mathrm{~cm}$; UCL-2948-32. 22. LM X-P (2.19); UCL-2948-31. 25. SEM distal view; Sample 27-261-33-1, $10 \mathrm{~cm}$; UCL-3000-32. 23, 24. Zeugrhabdotus erectus (Deflandre) Reinhardt. 23. LM X-P; Sample 27-261-33-1, 15 cm; UCL-2948-33. 24. SEM distal view; Sample 27-261-33-1, $15 \mathrm{~cm}$; UCL-2999-15. 